\title{
Design of Direct Injection Jet Ignition High Performance Naturally Aspirated Motorcycle Engines
}

\author{
Albert Boretti \\ Independent Scientist, Bundoora 3083, Australia; a.a.boretti@gmail.com \\ Received: 9 January 2019; Accepted: 3 February 2019; Published: 5 February 2019
}

\begin{abstract}
Thanks to the adoption of high pressure, direct injection and jet ignition, plus electrically assisted turbo-compounding, the fuel conversion efficiency of Fédération Internationale de l'Automobile (FIA) F1 engines has been spectacularly improved up to values above $46 \%$ peak power, and $50 \%$ peak efficiency, by running lean of stoichiometry stratified in a high boost, high compression ratio environment. Opposite, Federation Internationale de Motocyclisme (FIM) Moto-GP engines are still naturally aspirated, port injected, spark ignited, working with homogeneous mixtures. This old fashioned but highly optimized design is responsible for relatively low fuel conversion efficiencies, and yet delivers an outstanding specific power density of $200 \mathrm{~kW} /$ liter. The potential to improve the fuel conversion efficiency of Moto-GP engines through the adoption of direct injection and jet ignition, prevented by the current rules, is herein discussed based on simulations. As two-stroke engines may benefit from direct injection and jet ignition more than four-stroke engines, the opportunity of a return of two-stroke engines is also argued, similarly based on simulations. About the same power, but at a better fuel efficiency, of today's $1000 \mathrm{~cm}^{3}$ four stroke engines, may be obtained with lean stratified direct injection jet ignition engines, four-stroke of $1450 \mathrm{~cm}^{3}$, or two-stroke of $1050 \mathrm{~cm}^{3}$. About the same power and fuel efficiency may also be delivered with stoichiometric engines direct injection jet ignition two-stroke of $750 \mathrm{~cm}^{3}$.
\end{abstract}

Keywords: energy efficiency; power density; motorcycle engines; direct injection; jet ignition

\section{Introduction}

Direct injection and jet ignition have recently become popular in motor sport racing. Pressure to reduce fuel consumption has forced most of the Fédération Internationale de l'Automobile (FIA) F1 teams to adopt some sort of jet ignition in their direct injection turbocharged engines, where operation of the turbo is controlled by a motor-generator unit connected to the turbocharger shaft [1-3]. Running lean of stoichiometry and stratified, with a fast combustion of reduced cyclic variability, permitted by the enhanced ignition by multiple jets of hot, partially reacting products travelling the combustion chamber, the fuel consumption has been drastically reduced. Despite the engine is still controlled by the throttle, it operates lean of stoichiometry stratified with about $\lambda=1.45$.

F1 developments have been driven by the opportunity to boost the engine through turbocharging within the constraints of limited flow rate and limited amounts of fuel permitted per race. The F1 solution cannot be transferred immediately to Federation Internationale de Motocyclisme (FIM) Moto-GP engines without a change of rules, as the present Moto-GP engines do not have a limit on the fuel flow rate, the fuel permitted per race is not small enough to drive significant changes, and more than that, direct injection is implicitly forbidden by limiting the injection pressure to only 10 bar.

The jet ignition concept was developed by Prof. H.C. Watson and his co-workers in the late 1980s. Jet ignition was historically proposed to run the engine throttle-less and diesel-like by using homogeneous fuel air mixtures from stoichiometric to ultra-lean, [4-9]. 
Application to premixed mixtures has been fostered by ex-students of Prof. H.C. Watson, then working in Mahle and the University of Michigan since 2009. Developments by Mahle are reported in the use of jet ignition with premixed more than stratified mixtures [10-16].

Application to lean stratified mixtures by jet ignition has been mostly nurtured by the author, who was a collaborator of Prof. H.C. Watson from 2006 to 2009, working largely unsupported as independent scientist.

Jet ignition was proposed as a coupling to direct injection to work lean stratified, [17-21]. The advantage of the coupling was the opportunity to produce a central cloud of nearly stoichiometric mixture at the center of the combustion chamber with a surrounding cushion of air then bulk, high energy, ignited by multiple jets of hot reacting gases and rapidly and completely burned with reduced heat losses. Thanks to the late, fast injection, the cooling by fuel vaporization, plus the bulk ignition and rapid combustion, the end gases had much reduced opportunities to develop knock with reference to a same overall lean mixture introduced through the intake valves.

The latest improvements are the result of the intense research and development carried out by F1 teams after the change of engine rules introduced in 2014. This activity has been subjected to confidentiality agreements and it is not covered in literature. The latest developments in F1 racing are marginally reported in the literature, [1-3], without full details.

The F1 developments pave the way to better economies of passenger cars that could operate at a fixed lean lambda over the full range of speeds and loads. The major obstacle to the uptake of F1 like designs for passenger cars, apart from the costs, is the lack of a reliable after-treatment when the engine is run far from stoichiometry. This is clearly indicated by the difficulties of the lean burn diesel engines to meet the emission targets during real world driving, where, otherwise, the stoichiometric gasoline engines have less trouble thanks to the well-established three-way catalytic (TWC) converter after-treatment [22].

The major pollution issues of a lean burn engine for street bikes or passenger cars are the nitrogen oxides, and in minor extent, the soot. While both may be partially addressed through optimization of the injection and combustion systems, there is still a need for further research and development in the aftertreatment, as there is no off-the-shelf product providing similar performances of a three-way catalytic converter for stoichiometric engines. Otherwise, these engines could deliver unsurpassed fuel economy when covering driving cycles. F1 cars that are hybrid, deliver with a partial recovery of the braking energy limited to $120 \mathrm{~kW}$ and 2 MJ per lap fuel economies of 32-36\% over high speed, high acceleration and deceleration, laps of a racing circuit [23].

Figure 1 presents a sketch of a jet ignition device. This image is reproduced modified after [24]. When comparing directly injected (DI) jet ignited (JI) engines with port fuel injected (PFI) spark ignition (SI) engines, naturally aspirated, DI and JI have advantages and disadvantages. In terms of pure power output, the positive effect on the charge density of the fuel vaporization in the intake is lost. However, the lean stratified mixture by late direct injection is less prone to knock than the homogeneous, stoichiometric mixture by port fuel injection. This translates to the opportunity to use higher compression ratios. Additionally, with late direct injection, there is no opportunity that part of the fuel may bypass the combustion event escaping from the exhaust valves during scavenging. This also translates into a better fuel conversion efficiency, even if it is mostly at low loads. The concept is better detailed in [17-21]. It is proven by the achievements of F1 teams.

Even if JI may also be used with PFI and homogeneous mixtures, JI and DI translate in much faster combustion rates, especially running lean stratified. This permits better operation at the same overall $\lambda$, or about the same cyclic variability at a larger $\lambda$. Finally, a lean stratified mixture, burning in the bulk of the chamber, has reduced heat losses. This further improves the fuel conversion efficiency. Another downfall to mention of DI and JI, however, is the production of soot. Similar with the passenger cars, the option to run lean of stoichiometry street bikes also depends on the emission rules for real world driving, as every other aftertreatment is less efficient than the TWC converter for stoichiometric engines. 
Finally, the jet ignition device is still far from being a widespread industrial solution, with reliability and performances over prolonged operation still unassessed.

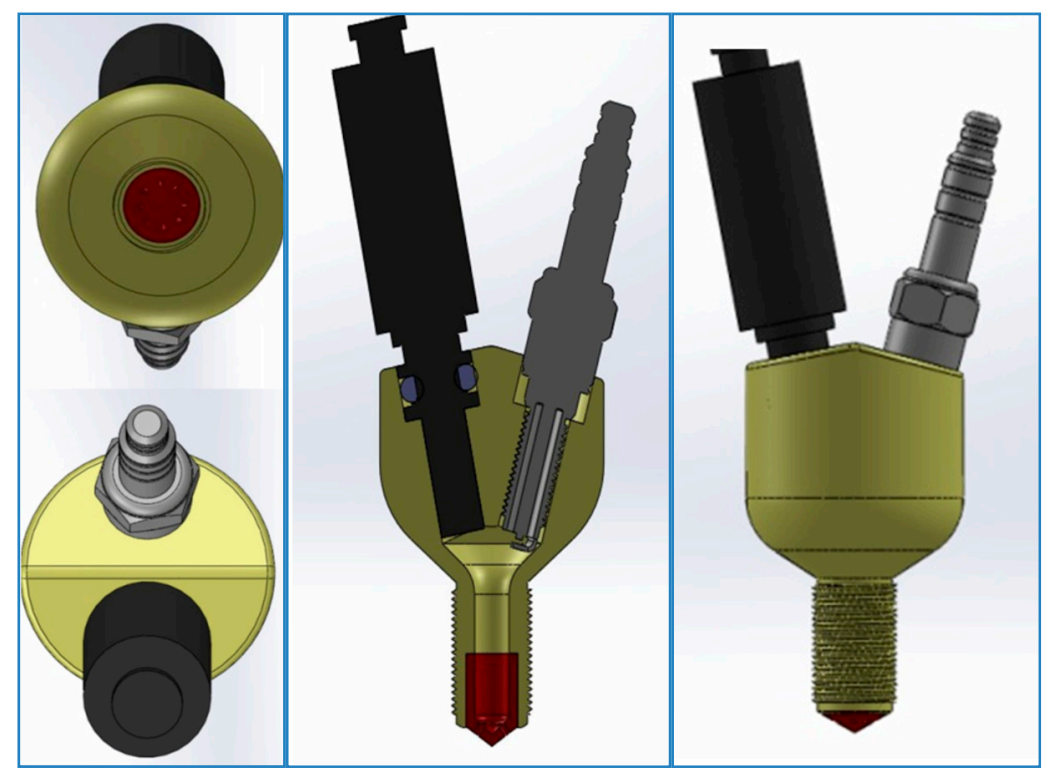

Figure 1. Jet ignition device.

To be considered, Moto-GP engines, as well as Moto-GP inspired street bikes, must maintain their high-tech high-performance character to keep alive a tradition of historical technological supremacy [25]. The revolutionary Guzzi V8 engine of 1954, one of the many examples of technical excellence in Moto-GP. Designed by Carcano, this $499 \mathrm{~cm}^{3}$ engine had bore $\mathrm{x}$ stroke of $44 \times 41 \mathrm{~mm}$; it was four-stroke, V8, liquid cooled, Double Over Head Camshaft (DOHC), featuring 8 Dell 'Orto $20 \mathrm{~mm}$ carburetors. It delivered a top power output of $58 \mathrm{~kW} @ 12,000 \mathrm{rpm}$. The Honda RC166 was another example of outstanding technical development. This $245 \mathrm{~cm}^{3}$, four-stroke, DOHC, 24-valve, inline six-cylinder engine, was able to reach speeds of 18,000 rpm delivering $46 \mathrm{~kW}$ of power. Every cylinder had a tiny bore of $41 \mathrm{~mm}$ and a stroke of only $31 \mathrm{~mm}$ for a unitary displaced volume of less than $41 \mathrm{~cm}^{3}$. The engine was air cooled. Fuel delivery was by 6 Keihin 22-mm carburetors. Two-stroke engines were the most popular choice in Grand Prix racing for half a century. The most successful Grand Prix engine of all the times was the Honda NSR500 engine, produced from 1984 to 2002. The Honda NSR500 engine of 1997 was a liquid-cooled $499 \mathrm{~cm}^{3} \mathrm{~V} 4$ engine able to deliver a top power output of $138 \mathrm{~kW} @ 12,000 \mathrm{rpm}$. Honda won $10500 \mathrm{~cm}^{3}$ World Championships with the NSR500 from 1984 to 2002. The domination of two-stroke engines in Moto-GP was ended by new rules introduced to favor the much more expensive, heavier, more complicated four-stroke engines having at the time a better environmental reputation (better fuel economy, reduced emissions) the latest advances in direct injection, jet ignition, and precise oiling may be put into question.

The aim of the present paper is to quantify advantages and disadvantages of DI and JI vs. PFI and SI in present Moto-GP engines, possible if only the 10 bars fuel pressure limit could be removed. This assessment is based on model simulations of the operation of a Moto-GP engine. The starting model is the numerical engine defined in [26], evolved to represent today's Moto-GP engines that have further evolved because of changed rules and further developments/refinements. Then, the option of a return of the two-stroke engines is also discussed, based on other simulations. Novelty of the paper is to show the potentials of direct injection and jet ignition for specific application to high performance motorcycle engines of two and four-stroke design. 


\section{Moto-GP Rules}

The 2018 rules of Moto-GP (ref. Section 2.4 of the FIA document) prescribe naturally aspirated four-stroke engines of up to $1000 \mathrm{~cm}^{3}$ with a limit on the number of cylinders and the bore/stroke ratio. In the fuel system, the maximum permitted relative fuel pressure is only $10 \mathrm{bars}$, at a re-circulated flow rate of 50 liters $/ \mathrm{h}$. The official regulator is fitted downstream of the fuel pump, ensuring that the maximum fuel pressure available to the injectors is never more than 10 bars. In the exhaust, variable length exhaust systems are not permitted. Exhaust Gas Recirculation (EGR) systems are also not permitted. The use of hydraulic and/or pneumatic pressurized powered systems are only allowed for cylinder inlet/exhaust valve springs. The use of engine lubricating oil for any purpose other than lubrication and cooling is not allowed. Variable valve timing and variable valve lift systems are not permitted. Moto-GP engines have a partial similarity with F1 engines that are $\mathrm{V} 690^{\circ}$, of displacement 1.6 liters, bore $80 \mathrm{~mm}$, stroke $53 \mathrm{~mm}, 4$ valves per cylinder, maximum revs 15,000 rpm, single turbo turbocharged electrically assisted, with direct injection 500 bar.

In terms of materials, the basic structure of the crankshaft and camshafts must be made from ferrous materials, steel or cast iron. Inserts of a different material are allowed in the crankshaft for the sole purpose of balancing. Pistons, cylinder heads, and cylinder blocks may not be composite structures, which use carbon or aramid fiber reinforcing materials. No parts of the engine may be made from metallic materials which have a specific modulus of elasticity greater than $50 \mathrm{Gpa} /\left(\mathrm{g} / \mathrm{cm}^{3}\right)$. MMC (Metal Matrix Composite) and FRM (Fiber Reinforced Metal) materials are forbidden. Hollow structure connecting rods are not permitted. Oil galleries of less than $2 \mathrm{~mm}$ diameter in the connecting rod are permitted.

The current designs of Moto-GP engines are those listed in Table 1. Basic principles driving the design of Moto-GP four-stroke engines are proposed in [27]. Prescribed minimum weights are $150 \mathrm{~kg}$ for up to $800 \mathrm{~cm}^{3}$ motorcycles (but no team uses these smaller engines) and $157 \mathrm{~kg}$ for motorcycles 801 to $1000 \mathrm{~cm}^{3}$. The fuel tank capacity is 22 liters.

Table 1. Moto-GP engines.

\begin{tabular}{ll}
\hline Parameter & Value \\
\hline Configuration & $75.5^{\circ}$ to $90^{\circ}$ V4 or Inline-four \\
Displacement & $1000 \mathrm{~cm}^{3}$ \\
Bore & $<81 \mathrm{~mm}$ \\
Cycle & Four-stroke \\
Valve-train & DOHC \\
No. of valves & four per cylinder \\
Valve control & Pneumatic \\
Fuel & Unleaded fuel \\
Fuel delivery & PFI \\
Max. Injection pressure & 10 bars \\
Aspiration & Naturally aspirated \\
Max. power & $190 \mathrm{~kW}$ \\
Rpm max. power & 17,500 to $18,000 \mathrm{rpm}$ \\
Lubrication & Wet sump \\
Cooling & Water cooled \\
Ignition & Spark plugs \\
\hline
\end{tabular}

All motorcycles must be fueled with unleaded petrol, which must comply with the FIM Grand Prix specification. Only fuel from the appointed fuel supplier is permitted. The specifications set characteristics such as Road Octane Number (RON) (limits 95.0 to 102.0), Motor Octane Number (MON) (limits 85.0 to 90.0 ) and density (limits 720.0 to $775.0 \mathrm{~kg} / \mathrm{m}^{3}$ at $15{ }^{\circ} \mathrm{C}$ ), oxygen, benzene, lead, distillation, and boiling point. However, the specifications do not prescribe the carbon (C) and hydrogen $(\mathrm{H})$ content, and the lower heating value (LHV) of the fuel. This does not permit making a comparison of fuel economy and carbon dioxide emissions with pump gasoline fuel. 


\section{Method}

Simulations are performed with state-of-the-art engine performance simulation codes starting from validated engine models and introducing single changes in the operational and geometric parameters defining the engines.

The engine models herein proposed represent friction through a correlation, and gas exchange and combustion through the numerical solution of zero and one-dimensional equations integrated in time. The brake mean effective pressure is obtained as the difference between the indicated mean effective pressure from the numerical computation and the friction mean effective pressure from the correlation. The baseline versions of the model have been validated versus measurements. The modified versions of the models, that are used to investigate the influence of the proposed variants, are expected to be accurate within a 10\% error. Simulations are only performed for power output, not for pollutant emissions.

With direct injection and jet ignition, the sensitivity to knock is reduced, and because the fuel vaporization within the cylinder reduces the charge temperature, injection occurs toward the end of the compression stroke; combustion is bulk initiated and rapidly completed. Hence, a higher compression ratio may be used with direct injection and jet ignition. By running lean stratified, the sensitivity to knock further reduces. Thus, the compression ratio may be further increased. With jet ignition, the combustion duration is drastically reduced, the completeness of combustion is improved, and the cyclic variability is reduced. The assumptions here made for the increments of compression ratio and the reduction of the combustion angle follow best practices based on experimental and numerical evidence [8,17-21].

\section{Four-Stroke Engine Results}

\subsection{Stoichiometric Full Load PFI SI and DI JI Engines}

Figures 2-4 present the computational results for DI and PFI engine models developed, as previously written, starting from the numerical engine defined in [26], evolved to represent today's Moto-GP engines that have further evolved because of changed rules and further developments/refinements. These are the wide-open throttle operating conditions working stoichiometric. The engines have bore $\times$ stroke $81 \mathrm{~mm} \times 48.5 \mathrm{~mm}$ and a connecting rod length of $115 \mathrm{~mm}$.

The stoichiometric PFI SI engine has a compression ratio of 13.5:1, completeness of combustion $98 \%$, angle of $50 \%$ combustion, 9 degrees of crank angle after top dead center, and combustion angle $10-90 \% 28$ degrees of crank angle. The injected fuel is taken as $90 \%$ liquid and 10\% vapor.

This engine has top power of $199.1 \mathrm{~kW}$ at 18,000 rpm. Fuel conversion efficiency at peak power is $32.8 \%$. Peak torque is $114.6 \mathrm{Nm}$ at $16,000 \mathrm{rpm}$. Fuel conversion efficiency at peak torque is $32.8 \%$. Peak fuel conversion efficiency is $37.8 \%$.

JI may also be used with PFI. The stoichiometric PFI JI engine may have a compression ratio of $14: 1$, thanks to the faster combustion. The angle for $10-90 \%$ combustion is taken as 14 degrees of crank angle.

This engine has a top power of $205.4 \mathrm{~kW}$ at 18,000 rpm. Fuel conversion efficiency at peak power is $33.9 \%$. Peak torque is $118.9 \mathrm{Nm}$ at $16,000 \mathrm{rpm}$. Fuel conversion efficiency at peak torque is $35.8 \%$. Peak fuel conversion efficiency is $38.8 \%$.

SI may also be used with DI. The stoichiometric SI DI engine may have a compression ratio of $14.5: 1$, thanks to the vaporization of the fuel within the cylinder lowering the temperature and the reduced residence time for knock to occur. The angle for 10-90\% combustion is taken as 28 degrees of crank angle. 
This engine has top power of $194.5 \mathrm{~kW}$ at $17,500 \mathrm{rpm}$. Fuel conversion efficiency at peak power is $33.5 \%$. Peak torque is $109.4 \mathrm{Nm}$ at $16,500 \mathrm{rpm}$. Fuel conversion efficiency at peak torque is $34.6 \%$. Peak fuel conversion efficiency is $37.9 \%$.

The stoichiometric DI JI engine finally has a compression ratio of $15: 1$ and an angle for $10-90 \%$ combustion at 14 degrees of the crank angle. The other parameters are the same as above. This engine has a top power of $200.6 \mathrm{~kW}$ at $17,500 \mathrm{rpm}$. Fuel conversion efficiency at peak power is $34.6 \%$. Peak torque is $112.8 \mathrm{Nm}$ at $16,500 \mathrm{rpm}$. Fuel conversion efficiency at peak torque is $35.7 \%$. Peak fuel conversion efficiency is $38.4 \%$.

Not relevant for road use, the PFI Moto-GP engine may have a better power output by running lightly rich, something that is not needed with DI. This, however, translates to a drastically reduced fuel economy.

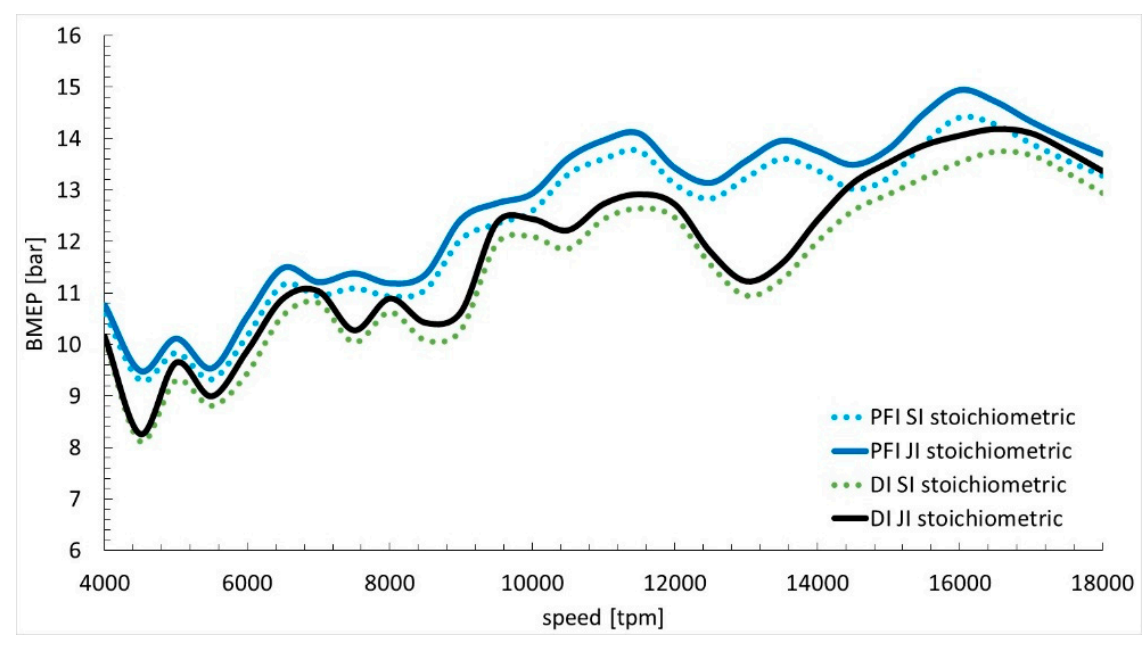

Figure 2. Brake mean effective pressure (BMEP) of stoichiometric engines.

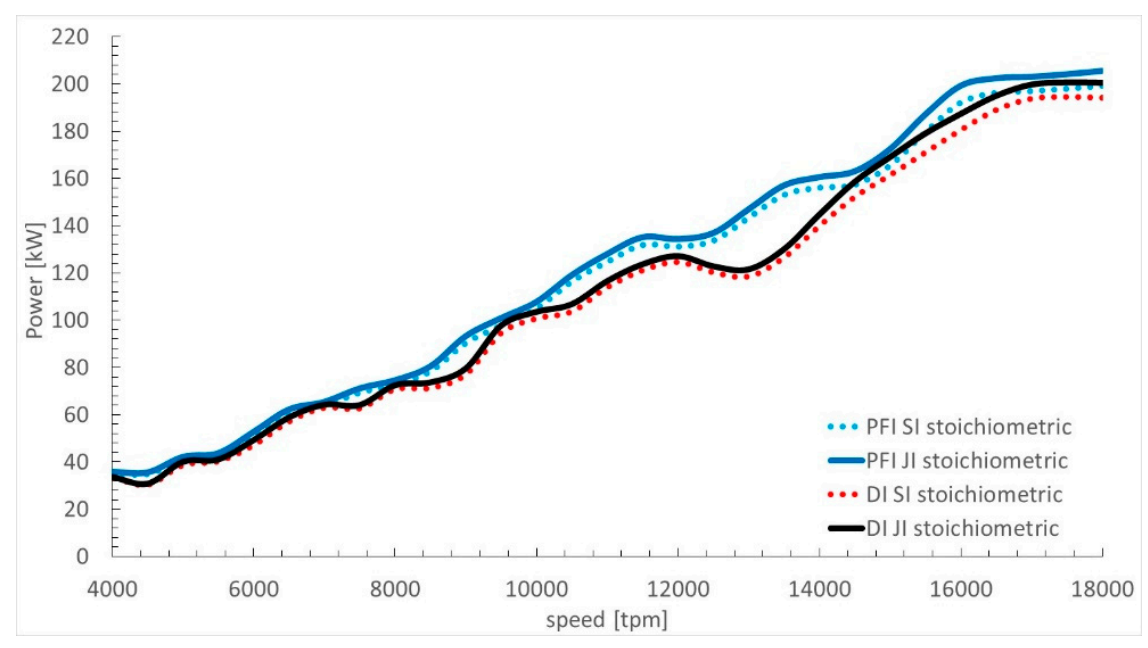

Figure 3. Power of stoichiometric engines. 


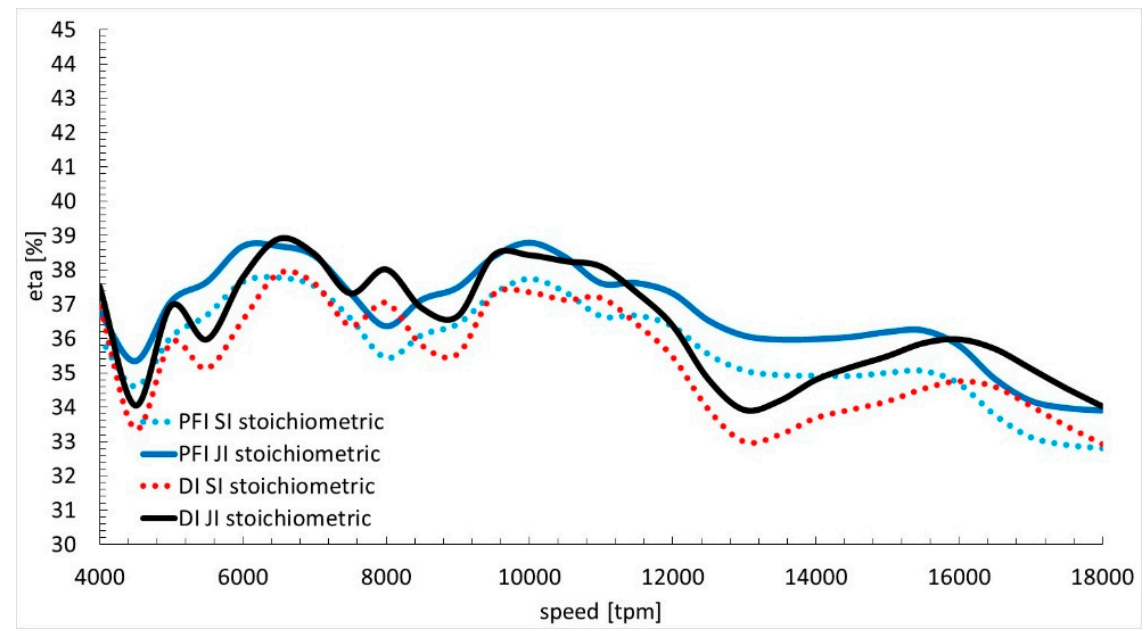

Figure 4. Fuel conversion efficiency of stoichiometric engines.

\subsection{Lean Part Load PFI SI and DI JI Engines}

While in principle JI may permit ultra-lean operation, i.e., load control throttle less by quantity of fuel injected, as it is done in F1 engines, the load control may be through the throttle. Here we investigate the opportunity to run leaner part-load on the stoichiometric engine.

Figures 5 and 6 present the BMEP and the fuel conversion efficiency of the modelled stoichiometric PFI SI and DI JI engines, $\lambda=1.2$ PFI SI engine, and $\lambda=1.45$ DI JI engine. There is no increment of compression ratio or reduction of heat transfer running lean with DI and JI.

The BMEP area between the lean and stoichiometric curves gives us an idea of the high efficiency zone of the map where the throttle closure does not penalize the operation. With the much leaner DI JI, the efficiency drastically improves. The above estimation of the efficiency advantages of the $\lambda=1.45 \mathrm{DI}$ JI engine is underrated; as in lean stratified operation, heat losses will be reduced as in the F1 experience $[1-3,23,28]$.

Both the DI and PFI engines may have further advantages from a more complete combustion if fitted with the jet ignition. This is presently neglected in the simulations of Figures 5 and 6 where only the fuel-air-ratio changes.

In F1 engines, JI ensures stable combustion of lean stratified mixtures by DI with equivalent air-to-fuel ratios above 1.4. The major advantage of JI, the opportunity to run much leaner of stoichiometry, especially with lean stratified mixtures from DI. The lean burn operation requires the development of a suitable aftertreatment in road bikes.

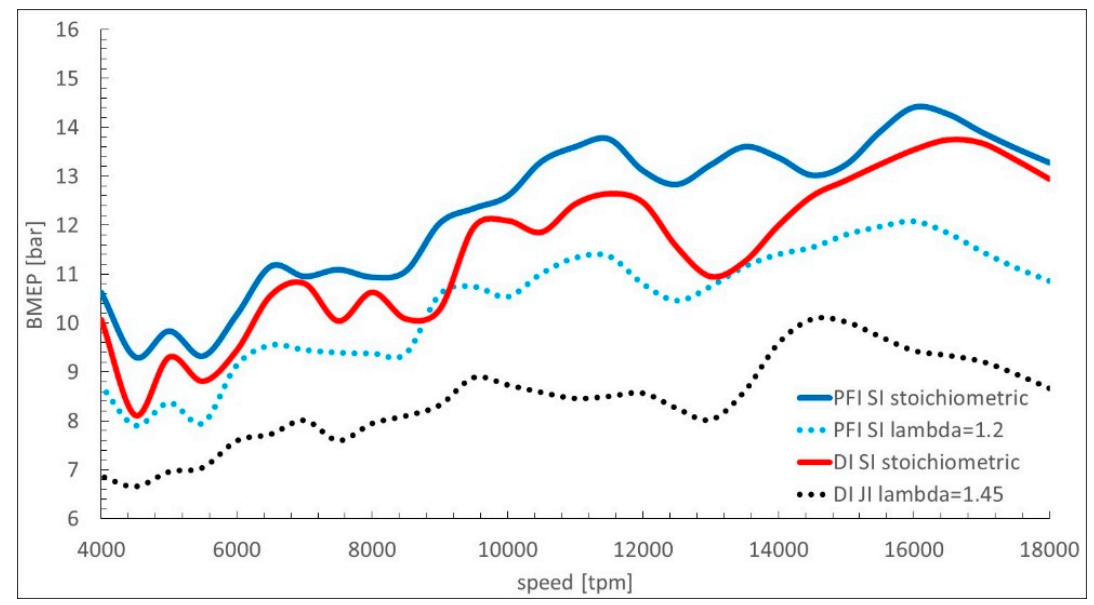

Figure 5. BMEP of engines stoichiometric and lean. 


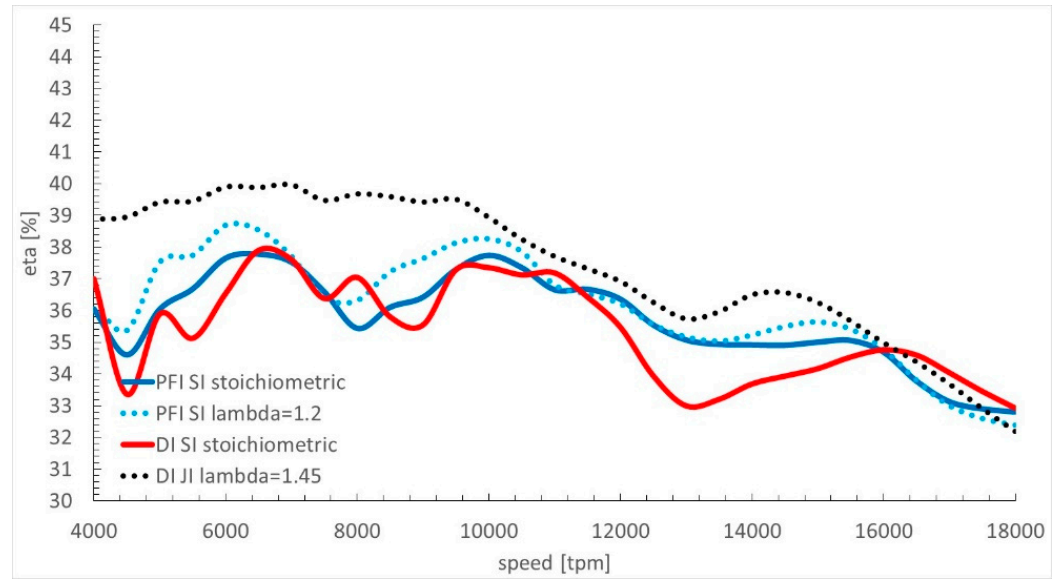

Figure 6. Fuel conversion efficiency of engines stoichiometric and lean.

\subsection{Lean Stratified Full Load DI JI Engine}

The benefits of direct injection and jet ignition are much larger than what is assumed in the computations of Figures 5 and 6 when working lean stratified full load, albeit at the price of a reduced power output. In FIA F1 engines, electrically assisted turbocharged engines featuring direct injection and some sort of jet ignition have achieved peak power fuel conversion efficiencies above $46 \%$, peak efficiencies above $50 \%$, and specific power densities of $340 \mathrm{~kW} /$ liter working lean stratified at about $\lambda=1.45[2,23]$.

The reduced amount of fuel needed for a globally lean of stoichiometry mixture, is injected towards the end of the compression stroke. The injected liquid fuel then vaporizes, cooling down the charge. The central cloud of a locally nearly stoichiometric fuel air mixture is then quickly bulk ignited by multiple jets of hot reacting products and rapidly burned with reduced heat losses thanks to the air cushion surrounding this inner cloud. The opportunity to develop knock is drastically reduced. Much higher compression ratios (or a much better compromise between boost and compression ratio in case of turbocharged engines) follow the design of the engine to work lean stratified $\lambda=1.45$ with direct injection and jet ignition.

With reference to the results of Figures 5 and 6 , the further benefits of an increment in the compression ratio from 15 to 17 , and a heat transfer coefficient reduced $10 \%$ with valves closed, translates into additional efficiency points and a slightly better output, as is shown in Figures 7 and 8 . Peak efficiency increases up to $41 \%$, while the brake mean effective pressure may increase up to 10.4 bar. As with naturally aspirated engines, it is impossible to partially compensate the power loss running lean by increasing the boost; larger displacement engines are needed to deliver the same performances at a better efficiency.

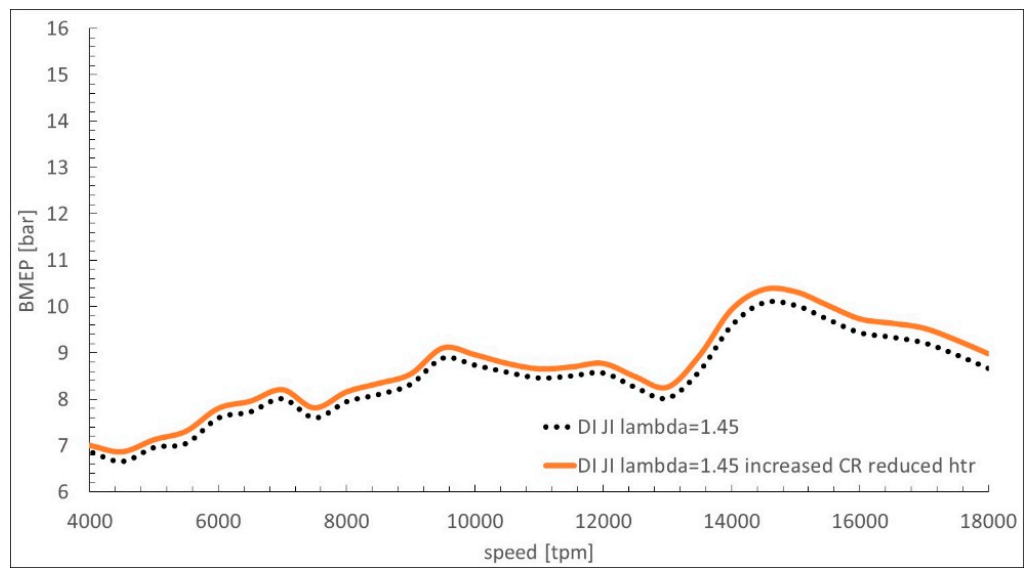

Figure 7. BMEP of lean stratified engines. 


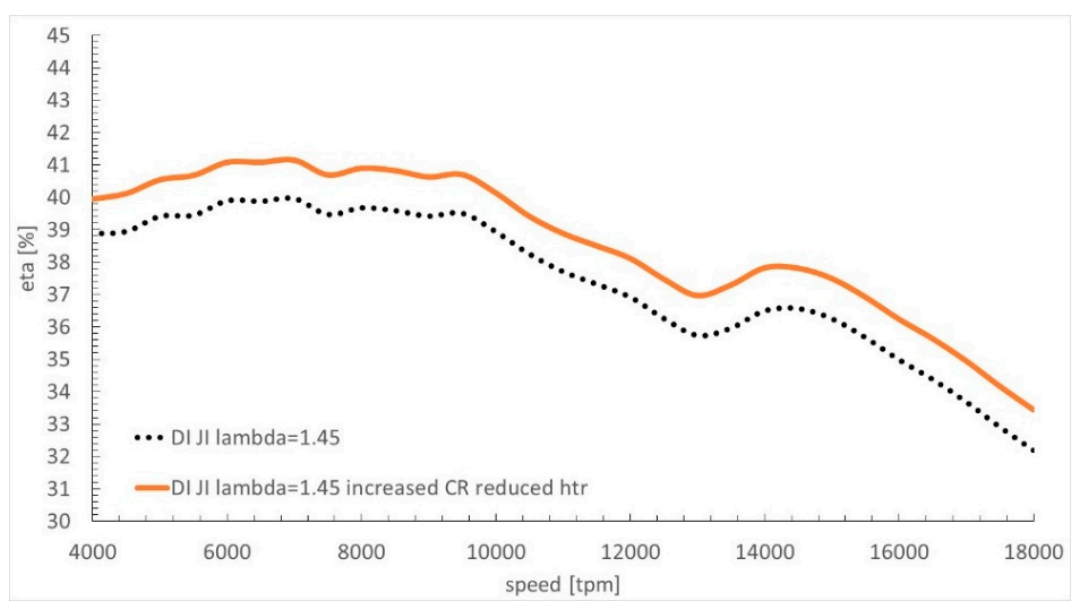

Figure 8. Fuel conversion efficiency of lean stratified engines.

\section{Two-Stroke Engine Results}

Thanks to direct injection and jet ignition, (and precise oiling) two-stroke engines may become competitive with four-stroke engines in terms of fuel economy and emissions [29,30]. The advantages of adopting high pressure, fast actuation, enhanced atomization gasoline injection, coupled with jet ignition, may deliver an otherwise very basic design as those of the racing engines of the latest from outstanding 1990s performances. Direct injection coupled to precise lubrication, where the oil is not mixed to the fuel but distributed where needed, has emerged as a potential game changer for the two-stroke engine. Direct injectors with pressures 500 bar and fast actuation that may deliver very well atomized fuel within very short time frames, for homogeneous and stratified mixtures, within the two-stroke engine combustion chamber starting after the time the exhaust ports close. Jet ignition can then permit a much faster and stable combustion.

\subsection{Stoichiometric Full Load and Lean Part Load DI JI Engines}

Figures 9-11 present the computed BMEP, power and fuel conversion efficiency of modelled stoichiometric and lean burn DI JI two-stroke engines. When compared to four stroke engines, the BMEP is reduced, but still the power density is much larger. The fuel conversion efficiency does not reduce dramatically in peak power and torque, even if this region is narrower than in four-stroke engines.

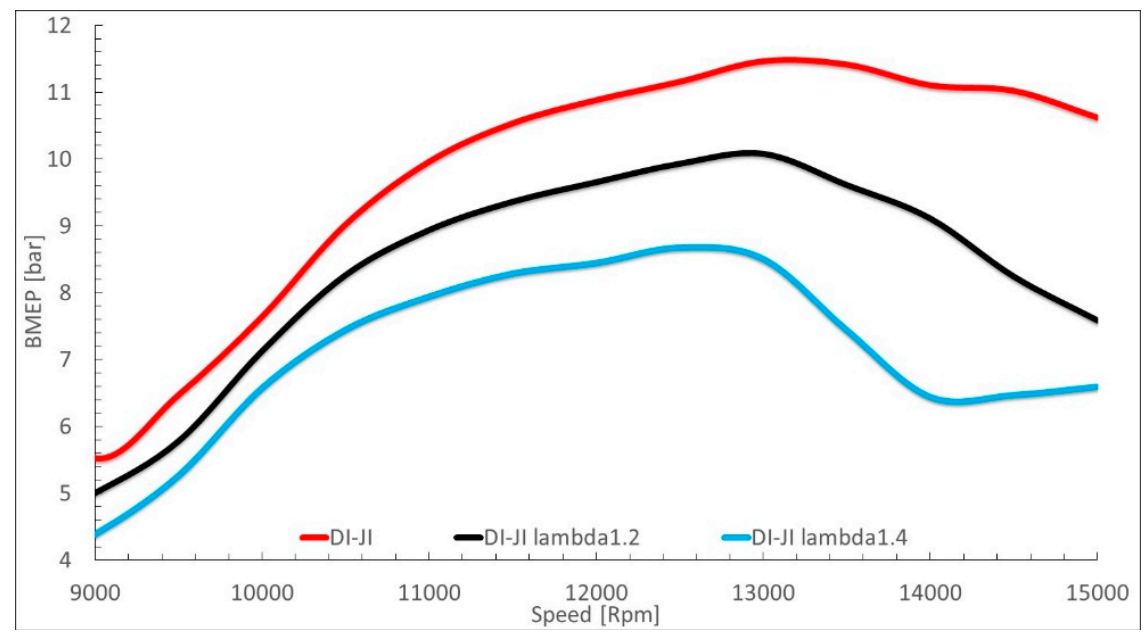

Figure 9. BMEP of stoichiometric and lean burn engines. 


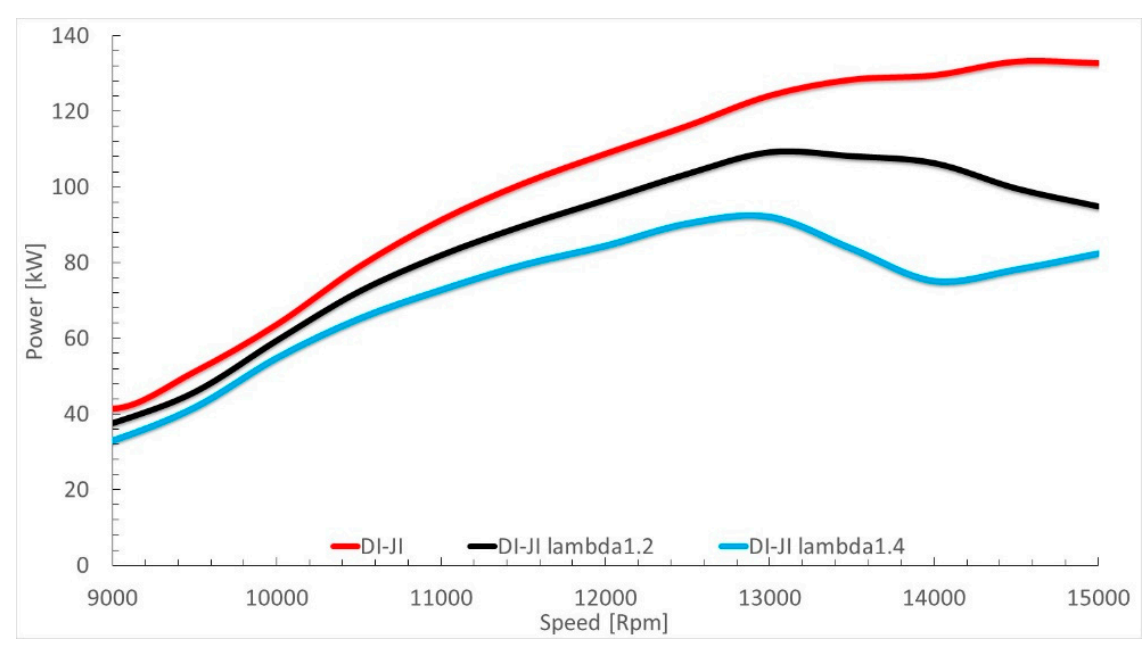

Figure 10. Power of stoichiometric and lean burn engines.

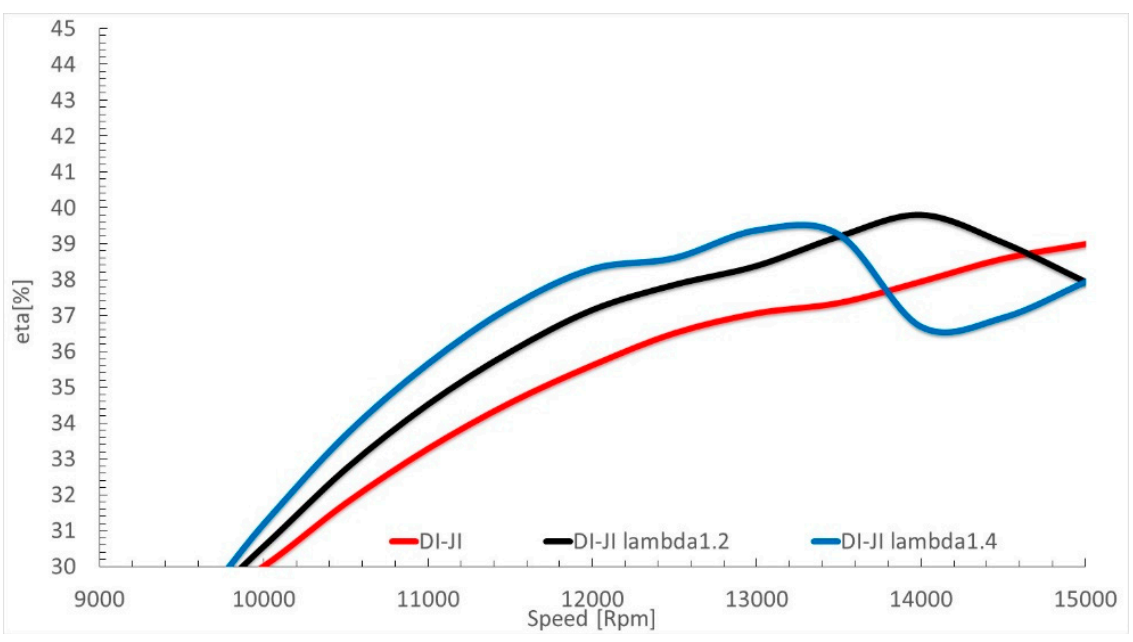

Figure 11. Fuel conversion efficiency of stoichiometric and lean burn engines.

It is evident how the efficiency penalty claimed to be the reason the much less expensive and much lighter two-stroke engines went out-mode is nowhere to be seen, as in the high rpm fully tuned region the engine has better efficiency of four-stroke engines and a much larger specific power.

\subsection{Lean Stratified Full Load DI JI Engine}

The above estimation of the efficiency advantages of the $\lambda=1.4 \mathrm{DI} \mathrm{JI}$ engine is underrated. The simulations of [29] were performed for not only constant heat transfer coefficient, but also constant compression ratio. In lean stratified operation, heat losses will be reduced, while the compression ratio can be increased; see the F1 experience and the simulations of the previous section. This may translate into further advantages. Figures 12 and 13 show the advantages obtained by increasing the compression ratio 13 to 14 and reducing the heat transfer coefficient with ports closed by $10 \%$.

Peak power fuel conversion efficiency approach the $40 \%$ mark, while the BMEP is almost 9 bars. Similarly, to what has been shown for naturally aspirated four-stroke engines, engine displacement needed to deliver the same performances of present four-stroke engines at a better efficiency with lean burn two-stroke engine will be more than one half, with better details to follow a more detailed computational work. 


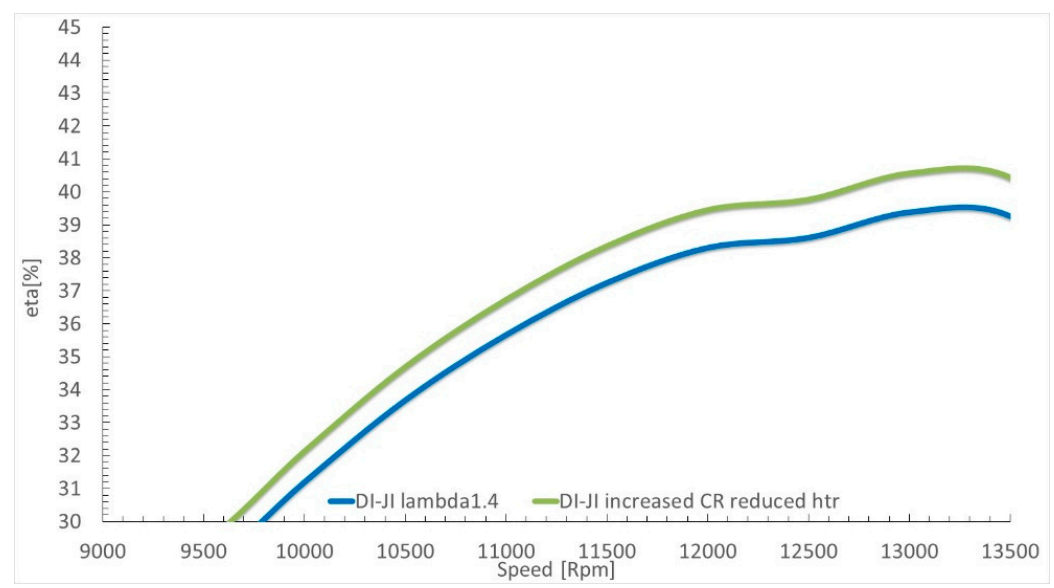

Figure 12. Fuel conversion efficiency of lean burn engines.

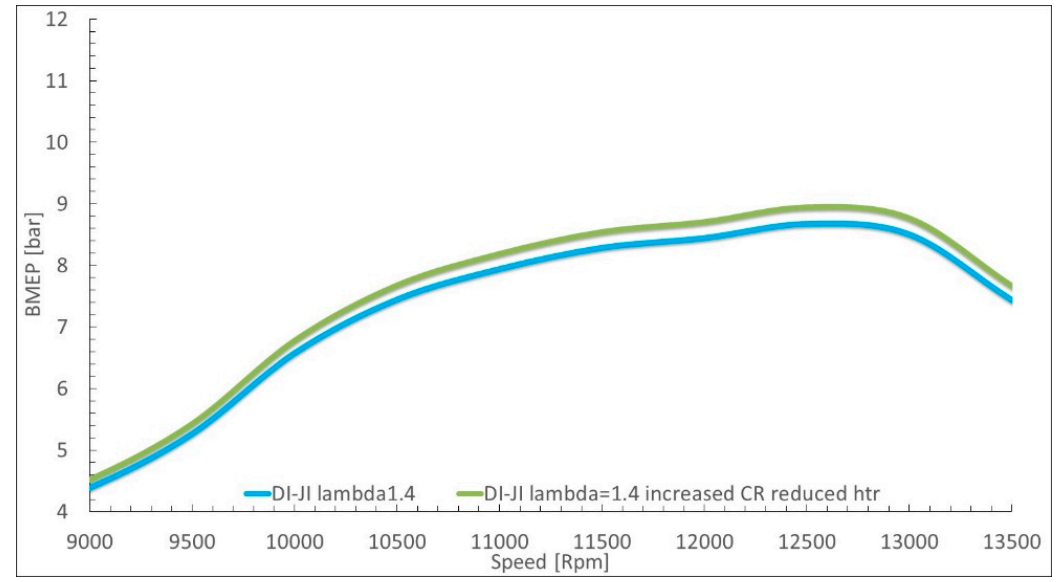

Figure 13. BMEP of lean burn engines.

\section{Discussion}

Naturally aspirated, directly injected racing engines do not have better wide open-throttle power/torque outputs than their port fuel injected counterparts. In Moto-GP, the best top end performances are still delivered by a fuel injector on top of the intake bell-mouth, thanks to the fuel vaporization in the intake tract. With direct injection, there is the advantage of having only air, rather than air and fuel, passing through the intake valves. For a stoichiometric fuel-air mixture, the fuel-to-air ratio is about 0.068 , i.e., with PFI, a $6.8 \%$ larger mass of air and fuel must pass through the intake valves versus the mass of air only of DI. However, PFI, especially with an injector atop of the intake bell mouth, drastically lower the temperature of the air-fuel mixture because of the latent heat of vaporization of the fuel. The positive effect of the temperature drop is larger than the negative effect of the additional mass that must pass through the intake valves.

DI has, however, a major advantage vs. PFI, the reduced sensitivity to knock. This is the result of two factors, the reduced time for a mixture of air and fuel to develop knock (with DI, the fuel is injected during the compression stroke, thus, the pockets of air fuel mixture are compressed less), and the temperature drop due to the vaporization of the fuel within the cylinder. DI permits larger compression ratios that translate in an increment of power/torque output, but, more than that, of fuel conversion efficiency. The actual increment of compression ratio may be larger than what is considered here. As the fuel needs time to mix with air, and the time needed for injection is limited, high flow rate, fine atomization injectors working high pressure with fast actuation are needed for a DI JI engine.

Jet ignition is providing a much faster, more complete, widespread ignition of the fuel-air mixture. Rather than starting from a single location, in between the spark plug electrodes, close to a wall, 
combustion is initiated by multiple jets of hot reaching products igniting the mixture across the combustion chamber. Jet ignition translates in a faster and more complete combustion. Experimental and computational experiences performed so far have shown the opportunity to achieve drastically reduced combustion angles with jet ignition, in homogeneous stoichiometric, homogeneous lean, and lean stratified mixtures. Therefore, jet ignition may improve the power/torque output thanks to this faster combustion. Jet ignition may be coupled to both PFI and DI working homogeneous, stochiometric or lean, while only DI may permit lean stratified operation. Improvements are larger running leaner. Jet ignition is also an enabler of an increased compression ratio.

The advantages of DI JI vs. PFI SI are thus mostly the higher compression ratio, the generally faster combustion rate, the opportunity to run much leaner stratified rather than homogeneous, no fuel escaping the combustion event, and finally the reduced heat losses running lean stratified rather than homogeneous. These advantages have been only partially accounted for in the models.

Unfortunately, in road bikes, the engines are now operated closed loop, stoichiometric in the map area of concern for the specific emission cycle. With the further development of real-world driving cycles, it is expected that the closed loop, stochiometric operation will be extended to every possible operating condition. Running lean, the three-way catalytic converter does not work properly, and lean burn catalysts are not yet as developed as the three-way catalytic converter. Negative for DI, is the opportunity to produce soot. This may be addressed with better injectors.

Two-stroke engines may benefit much more than four-stroke engines from DI and jet ignition. Very high speed, high flow rate and high atomization injectors are needed. With the addition of precise oiling-No oil mixed with fuel but delivered where needed-Engines may be lighter, more powerful and more fuel efficient than four-stroke.

\section{Conclusions}

Four-stroke Moto-GP engines may deliver better fuel efficiency, with about the same top performances, by adopting direct injection and jet ignition. Fuel efficiency may drastically improve running lean stratified, albeit at the expenses of reduced power density. This efficiency improvement may not necessarily be immediately transferred to road bikes, as during real world driving, the engines of road bikes cannot presently run lean of stoichiometry, as otherwise the emissions will be large. However, new emission rules requesting real world driving compliance are still missing, and the development of lean catalysts is a need of many other applications.

Two stroke engines may benefit even more than four-stroke engines from direct injection and jet ignition, that coupled to precise oiling, may permit production of much lighter engines, with a better specific power, but close to four stroke fuel economy, albeit with a reduced speed range, but at reduced costs.

The sporting rules should be relaxed to permit the best outcomes for racing and street bikes. A reduction of the fuel tank capacity, with no opportunity to refuel, will force the manufacturers to explore the best option available in four-stroke and two-stroke engines of better equalized displacements, but a free number of cylinders, free bore and stroke, free fuel delivery, reduced minimum equalized weight, and freedom to adopt direct injection and jet ignition.

Funding: This research received no external funding.

Conflicts of Interest: The authors declare no conflict of interest.

\section{References}

1. Boretti, A. F1 style MGU-H applied to the turbocharger of a gasoline hybrid electric passenger car. Nonlinear Eng. 2017. [CrossRef]

2. Boretti, A. Progress of Direct Injection and Jet Ignition in Throttle Controlled Engines; SAE Technical Paper 2019-26-0045; SAE: Warrendale, PA, USA, 2019. [CrossRef] 
3. Boretti, A. Transient positive ignition internal combustion engines have now surpassed the $50 \%$ fuel conversion efficiency barrier. Int. J. Hydrog. Energy 2019, in press.

4. Lumsden, G.; Watson, H. Optimum Control of an S.I. Engine with a $\lambda=5$ Capability; SAE Technical Paper 950689; SAE: Warrendale, PA, USA, 1995. [CrossRef]

5. Kyaw, Z.H.; Watson, H.C. Hydrogen assisted jet ignition for near elimination of NOx and cyclic variability in the SI Engine. In Symposium (International) on Combustion; Elsevier: Amsterdam, The Netherlands, 1992.

6. Glasson, N.; Lumsden, G.; Dingli, R.; Watson, H. Development of the HAJI System for a Multi-Cylinder Spark Ignition Engine; SAE Technical Paper 961104; SAE: Warrendale, PA, USA, 1996. [CrossRef]

7. Lawrence, J.; Watson, H. Hydrocarbon Emissions from a HAJI Equipped Ultra-lean Burn SI Engine; SAE Technical Paper 980044; SAE: Warrendale, PA, USA, 1998.

8. Boretti, A.; Brear, M.; Watson, H. Experimental and numerical study of a hydrogen fuelled I.C. engine fitted with the hydrogen assisted jet ignition system. In Proceedings of the Sixteenth Australasian Fluid Mechanics Conference, Gold Coast, Australia, 3-7 December 2007.

9. Boretti, A.; Watson, H.C. Enhanced combustion by jet ignition in a turbocharged cryogenic port fuel injected hydrogen engine. Int. J. Hydrog. Energy 2009, 34, 2511-2516. [CrossRef]

10. Attard, W.; Fraser, N.; Parsons, P.; Toulson, E. A Turbulent Jet Ignition Pre-Chamber Combustion System for Large Fuel Economy Improvements in a Modern Vehicle Powertrain. SAE Int. J. Eng. 2010, 3, $20-37$. [CrossRef]

11. Attard, W.; Blaxill, H. A Lean Burn Gasoline Fueled Pre-Chamber Jet Ignition Combustion System Achieving High Efficiency and Low NOx at Part Load; SAE Technical Paper 2012-01-1146; SAE: Warrendale, PA, USA, 2012. [CrossRef]

12. Toulson, E.; Schock, H.J.; Attard, W.P. A Review of Pre-Chamber-Initiated Jet Ignition Combustion Systems; SAE Technical Paper 2010-01-2263; SAE: Warrendale, PA, USA, 2010.

13. Attard, W.P.; Parsons, P. Flame kernel development for a spark-initiated pre-chamber combustion system capable of high load, high efficiency and near zero NOx emissions. SAE Int. J. Eng. 2010, 3, 408-427. [CrossRef]

14. Attard, W.P.; Blaxill, H. A gasoline fueled pre-chamber jet ignition combustion system at unthrottled conditions. SAE Int. J. Eng. 2012, 5, 315-329. [CrossRef]

15. Attard, W.P.; Blaxill, H. A single fuel pre-chamber jet ignition powertrain achieving high load, high efficiency and near zero NOx emissions. SAE Int. J. Eng. 2012, 5, 734-746. [CrossRef]

16. Attard, W.P.; Blaxill, H.; Anderson, E.K.; Litke, P. Knock limit extension with a gasoline fueled pre-chamber jet igniter in a modern vehicle powertrain. SAE Int. J. Eng. 2012, 5, 1201-1215. [CrossRef]

17. Boretti, A.; Watson, H.C. The lean burn direct-injection jet-ignition turbocharged liquid phase LPG engine. In Proceedings of the 15th Asia Pacific Automotive Engineering Conference, Hanoi, Vietnam, 26-28 October 2009.

18. Boretti, A.; Watson, H.C. The Lean Burn Direct-Injection Jet-Ignition Flexi Gas Fuel LPG/CNG Engine; SAE Technical Paper 2009-01-2790; SAE: Warrendale, PA, USA, 2019. [CrossRef]

19. Boretti, A.; Watson, H.C. The lean burn direct-injection jet-ignition gas engine. Int. J. Hydrog. Energy 2009, 34, 7835-7841. [CrossRef]

20. Boretti, A.; Watson, C.H.; Tempia, A. Computational analysis of the lean burn direct-injection jet-ignition hydrogen engine. Proc. Inst. Mech. Eng. Part D 2009, 224, 261-269. [CrossRef]

21. Boretti, A.; Paudel, R.; Tempia, A. Experimental and computational analysis of the combustion evolution in direct injection spark controlled jet ignition engines fuelled with gaseous fuels. Proc. Inst. Mech. Eng. Part D 2010, 224, 1241-1261. [CrossRef]

22. Boretti, A. The Future of the Internal Combustion Engine after "Diesel-Gate"; SAE Technical Paper 2017-28-1933; SAE: Warrendale, PA, USA, 2017. [CrossRef]

23. Boretti, A. Energy flow of a 2018 FIA F1 racing car and proposed changes to the powertrain rules. Nonlinear Eng. 2019, in press.

24. Boretti, A.; Jiang, S. Development of a two stroke direct injection jet ignition compressed natural gas engine. J. Power Technol. 2014, 94, 145-152.

25. Boretti, A. Engine Design Concepts for World Championship Grand Prix Motorcycles; SAE: Warrendale, PA, USA, 2012. 
26. Boretti, A.; Scalzo, J. Design of 65-Degree v4 Moto-GP Engines with Pneumatic Poppet Valves or Rotary Valves; SAE Technical Paper 2015-26-0176; SAE: Warrendale, PA, USA, 2015. [CrossRef]

27. Boretti, A. Parametric Design of FIM WGP Engines; SAE Technical Paper 2002-01-3317; SAE: Warrendale, PA, USA, 2002. [CrossRef]

28. Boretti, A. Advances in Turbocharged Racing Engines SAE International, Product Code PT-199; SAE: Warrendale, PA, USA, 2019.

29. Boretti, A. Numerical modelling of the operation of a novel two-stroke V4 engine. Int. J. Eng. Technol. Innov. 2017, 7, 69-77.

30. Boretti, A.; Jiang, S.; Scalzo, J. A Naturally Aspirated Four Stroke Racing Engine with One Intake and One Exhaust Horizontal Rotary Valve Per Cylinder and Central Direct Injection and Ignition by Spark or Jet; SAE Technical Paper 2015-01-0006; SAE: Warrendale, PA, USA, 2015. [CrossRef]

(C) 2019 by the author. Licensee MDPI, Basel, Switzerland. This article is an open access article distributed under the terms and conditions of the Creative Commons Attribution (CC BY) license (http://creativecommons.org/licenses/by/4.0/). 